\title{
Oplophorid shrimps (Decapoda: Caridea: Oplophoridae) in the Gulf of Mexico and Caribbean Sea from the collec- tions of the research vessels Alaminos, Oregon and Oregon II
}

\section{Linda H. Pequegnat and Mary K. Wicksten}

\begin{abstract}
At least 25 species of oplophorid shrimp have been collected in the Gulf of Mexico and Caribbean Sea. Of these, 21 are pelagic and four commonly are found in samples taken at or near the sea floor. Acanthephyra pelagica and Heterogenys microphthalma are reported for the first time from the Gulf of Mexico. Acanthephyra acutifrons, A. stylorostratis, Meningodora marptocheles, Ephyrina benedicti and Notostomus elegans are reported for the first time from the Caribbean Sea. We provide comments on the morphology of $A$. curtirostris, $A$. eximia, A. pelagica, Hymenodora spp. and Meningodora mollis.
\end{abstract}

\section{Introduction}

Species of the family Oplophoridae are among the most common large midwater crustaceans. Both midwater and benthic species commonly are collected in benthic sampling gear if there is no closing device employed at depth. Oplophorids were included in the results of exploratory fishing studies of the vessels Oregon and Oregon II in the Gulf of Mexico and Caribbean (Springer \& Bullis, 1956; Thompson, 1963; Bullis \& Thompson, 1965). These cruises concentrated on particular areas, especially the northeastern Gulf of Mexico, and employed mostly benthic trawls. Later papers by Hopkins \& Lancraft (1984) and Hopkins, Gartner \& Flock (1989) included reports of oplophorids and other pelagic decapods from the northeastern Gulf of
Mexico (in the vicinity of $27^{\circ} \mathrm{N}, 86^{\circ} \mathrm{W}$ ).

In 1965-1973, oplophorids and other invertebrates were collected during deep-sea sampling cruises of the R.V. Alaminos in the Gulf of Mexico and Caribbean Sea. One of us (LHP) previously reported on the primarily benthic families of caridean shrimps from these cruises (Pequegnat, 1970). The Oplophoridae were not included in that work, but maps of their distributions were included in the Folio Atlas of the Gulf of Mexico Deep-Sea Fauna (Pequegnat, 1971).

A great amount of additional material of the Oplophoridae has become available since 1971. In this paper, we summarize information on distribution by depth and geographic location of oplophorids in the Gulf of Mexico. We note first records of species in the Gulf of Mexico and Caribbean Sea. We give sizes for each species. We compare the oplophorid fauna of the Gulf of Mexico and Caribbean Sea with that of the northern Atlantic in general and the tropical eastern Pacific.

\section{Materials and Methods}

The Alaminos deep-sea collections, under the direction of the late Willis E. Pequegnat, were carried out during 18 cruises between 1965-1973. On 12 of these cruises the IsaacsKidd midwater trawl was used, often with opening-closing devices for more precise depth sampling. Many mesopelagic and bathypelagic animals also were caught during benthic sampling if the gear was open throughout the water column on the way up and down. See Pequegnat and Pequegnat 
(1970) and Pequegnat et al. (1970) for station records and information on the sampling gear. Stations of the Alaminos are designated by the letter "A" following the last two digits of the year in which the sample was taken.

Additional specimens were taken incidental to benthic sampling during the LGL Ecological Research Associates/U.S. Department of the Interior Minerals Management Service Northern Gulf of Mexico Continental Slope study (NGOMCS) in 1984-1985. Other specimens were collected incidentally to benthic sampling during exploratory fisheries cruises of the fishing vessel Success in 1989-1990 and the Deep Gulf of Mexico Benthos Study (DGoMB) of 2000-2004. We also examined a specimen taken by trawl at station JSSD -3 by the Universidad Autónoma de Mexico (UNAM), Elva Escobar-Briones, collector. With few exceptions, data on temperature and salinity at depth do not accompany the specimens. Most of the specimens originally were preserved in $10 \%$ formalin and later transferred to $70 \%$ or $95 \%$ ethanol for permanent storage.

Samples collected by the cruises of the U.S. National Marine Fisheries vessels Oregon and Oregon II were taken by trawls. The interested reader should consult the works of Springer \& Bullis (1956), Thompson (1963) and Bullis \& Thompson (1965) for further information on equipment and station locations. Hundreds of specimens of deep-sea crustaceans, including oplophorids, from these cruises were donated to the Texas Cooperative Wildlife Collection (TCWC) at Texas A\&M University. These were sorted and identified to species in 2000-2002.

Most of the specimens discussed here are housed in the Marine Invertebrate Collection of the TCWC. We examined a single specimen from the collections of UNAM. One of us (LHP) compared selected specimens from the Gulf of Mexico with specimens from the United States National Museum of Natural History (USNM). We compared specimens of Acanthephyra cur- tirostris and $A$. eximia from the Gulf of Mexico and Caribbean with similar specimens from the Pacific from the collections of Scripps Institution of Oceanography (SIO).

Specimens previously mentioned by Pequegnat (1970) as belonging to the Department of Oceanography, Texas A\&M University, were incorporated into the TCWC in 2000. All of these specimens have been catalogued in writing. Incorporation of the catalog into digital format is in progress. Interested researchers should contact the TCWC for more detailed records until such time as the complete catalog is available online.

Genera and species are presented in alphabetical order. We provide previous records from the literature as given by Chace (1940, 1947, 1986), Springer \& Bullis (1956), Thompson (1963), Bullis \& Thompson (1965), Crosnier \& Forest (1983), Hopkins \& Lancraft (1984), Hopkins et al. (1989), Wasmer (1993), Hendrickx \& Estrada-Navarrete $(1989,1996)$ and Wicksten (2002). Interested readers should consult these works for more detailed records and synonymies. We added records not presented in these works. We give complete station data if the species represents a first record in the Gulf of Mexico or Caribbean Sea, or if we examined specimens from only one station.

We were curious to see if the distribution of oplophorids might show east-west differences in the Gulf of Mexico, following the pattern of flow of the Loop Current. In our descriptions of geographic range, we arbitrarily divided the Gulf into four quadrants (Fig. 1). These are abbreviated as NW (northwest), NE (northeast), SW (southwest) and SE (southeast). The $90^{\text {th }}$ parallel approximates the delta of the Mississippi River; the $25^{\text {th }}$ parallel is close to the southernmost end of the Florida peninsula. The southeast quadrant contains the area between $25^{\circ} \mathrm{N}$ latitude and north of the coast of Cuba, which, strictly speaking, could be considered to be part of the Straits of Florida. (See Wicksten \& Packard, 2005, for 


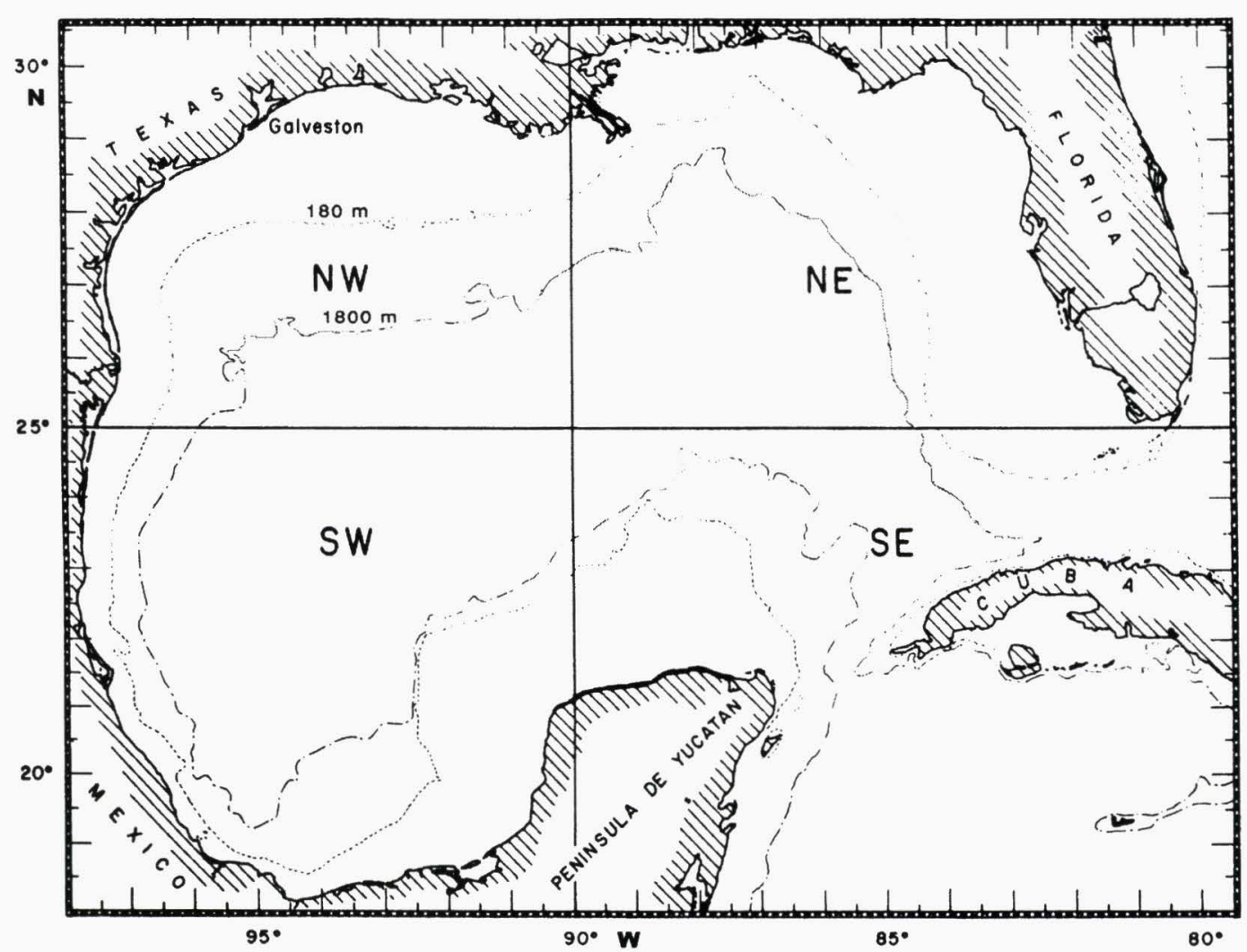

Fig. 1. Subdivisions of the Gulf of Mexico into quadrants along $25^{\circ} 00^{\prime} \mathrm{N}$ latitude and $90^{\circ} 00^{\prime} \mathrm{W}$ longitude (adapted from Pequegnat \& Pequegnat, 1970).

comments on the distinct benthic decapod fauna of the area). We consider the area southward from Cabo Catoche, Yucatán and the westernmost tip of Cuba to belong to the Straits of Yucatán and therefore the Caribbean Sea.

Depth range gives the maximum depth at which a particular sample was taken in the Gulf of Mexico and does not necessarily mean that the species was collected at that depth. A sample collected in an open net that reached $3000 \mathrm{~m}$ might have been taken anywhere from that depth to the surface. We define mesopelagic as depths above $1500 \mathrm{~m}$ and bathypelagic for depths greater than $1500 \mathrm{~m}$. The maximum depth at which samples were taken in the Gulf of Mexico was $3840 \mathrm{~m}$, in the Caribbean, $4557 \mathrm{~m}$.

Size of each species is carapace length
(CL) measured from the orbit to the posterior margin of the carapace in millimeters. Specimens were sexed unless the abdomen and pleopods were broken, or the specimen was too small to determine the sex.

We include remarks on range, anatomy or identification where such information has not been provided previously.

\section{Results}

Species of Oplophoridae Genus Acanthephyra

Acanthephyra acanthitelsonis Bate, 1888

Material examined. - 33 specimens from 24 stations, throughout Gulf; also seven specimens from five Caribbean stations.

Depth range. -1000-3548 m, mesopelag- 
ic and upper bathypelagic. Most specimens were taken above bottom depths of at least $1000 \mathrm{~m}$.

Size. - Male CL to 21; female to 22.

Previous geographic and depth reports.- Central and South Atlantic between $14^{\circ} \mathrm{N}$ and $28^{\circ} \mathrm{S}$, Gulf of Mexico and Caribbean Sea, eastern Atlantic off West Africa; mesopelagic (Kemp, 1939; Springer \& Bullis, 1956; Crosnier \& Forest, 1973; Hopkins \& Lancraft, 1984; Chace, 1986; Hopkins et al., 1989).

\section{Acanthephyra acutifrons Bate, 1888}

Material examined. - 25 specimens from 19 stations, throughout Gulf. Also one female from western Caribbean Sea: sta. $70 \mathrm{~A} 10-20,16^{\circ} 24^{\prime} \mathrm{N}, 84^{\circ} 37^{\prime} \mathrm{W}, 1079-1170 \mathrm{~m}$, trawl, 11 July 1970 . This is the first report of this species from the Caribbean Sea.

Depth range. - 357-3237 $\mathrm{m}$, lower mesopelagic and bathypelagic. Most specimens were taken in trawls with a maximum depth of $1200 \mathrm{~m}$ or more.

Size. - Male CL to 26, female to 49.

Previous geographic and depth reports. - Both eastern and western tropical and subtropical Atlantic, including the "West Indian region”, Gulf of Mexico, and southwestern Brazil; Indian Ocean, Indonesia; mesopelagic (Chace, 1940, 1947, 1986; Springer \& Bullis, 1956; Thompson, 1963; Bullis \& Thompson, 1965; Hopkins \& Lancraft, 1984; Hopkins et al., 1989; Cardoso \& Young, 2005).

Remarks. - Juveniles were taken in midwater samples some $700-2000 \mathrm{~m}$ above the sea floor at night. The only sexually mature individual collected was a female taken when a midwater trawl sampled to within $122 \mathrm{~m}$ of the sea floor, also at night. This suggests that juveniles may live in midwater at more shallow depths than adults.

\section{Acanthephyra armata A. Milne-Edwards 1881}

Material examined. - 60 specimens from 11 stations, throughout Gulf; also 220 specimens from 22 Caribbean stations.
Depth range. - 732-2880 m but usually in trawls with a maximum depth of $1100 \mathrm{~m}$ or less.

Size. - Male CL to 42 , female to 35 .

Previous geographic and depth reports.- Western Atlantic, Gulf of Mexico and Caribbean Sea, southwestern Indian Ocean, Philippines, Indonesia; 365-1570 m (Springer \& Bullis, 1956; Thompson, 1963; Bullis \& Thompson, 1965; Takeda \& Okutani, 1983; Chace, 1986).

Remarks.- Acanthephyra armata consistently has been collected in benthic or nearbottom trawls, not in midwater samples. We agree with Chace (1986) in considering $A$. armata to be a benthic species occurring on continental and insular slopes. The species seems to have a very patchy numerical distribution. Although only one to five specimens were taken in the majority of trawls, there were 20 at Oregon II station 10649 $\left(29^{\circ} 4^{\prime} \mathrm{N}, 88^{\circ} 16^{\prime} \mathrm{W}, 718 \mathrm{~m}\right.$, 25 June 1969 , TCWC 2-7019) and 112 at a Caribbean station (Oregon station 5930, $15^{\circ} 38^{\prime} \mathrm{N}, 61^{\circ} 7^{\prime} \mathrm{W}$, 809 m, 5 March 1966, TCWC 2-7606).

Springer \& Bullis (1956) reported $A$. armata from a depth of $37 \mathrm{~m}$ from Oregon station 560 . We suspect that the station data was in error, for there are no other reports of this species so shallow.

\section{Acanthephyra brevirostris Smith, 1885}

Material examined. - 13 specimens from 10 stations, NW, SW and SE Gulf; no Caribbean specimens.

Depth range. - 1435-3292 m, bathypelagic. Only one specimen was taken at a station with a maximum depth of less than $2000 \mathrm{~m}$.

Size. - Male CL to 16 , female to 19 .

Previous geographic and depth reports. - North and South Atlantic including Gulf of Mexico, southwestern Indian Ocean, eastern tropical Pacific; $1200-5300$ m, bathypelagic (Chace, 1940, 1947, 1986; Springer \& Bullis, 1956).

Remarks.- The specimens taken by the Alaminos differ from Smith's (1885) description in that the spine on the third abdominal 
somite does not reach to the end of the fourth abdominal segment and is not as fleshy as compared with Smith's (1886) specimen from Albatross sta. 2566 (USNM cat. no. 10832). The Alaminos specimens also have a small spine on the anteroventral surface of the rostrum, resembling more closely the Pacific forms of this species (see Faxon, 1895, p. 167).

Acanthephyra curtirostris Wood-Mason, 1891

Material examined. - 67 specimens from 40 stations, throughout Gulf; also 10 specimens from six Caribbean stations.

Depth range. $-486-2600 \mathrm{~m}$, usually at $1200 \mathrm{~m}$ and deeper, mesopelagic.

Size. - Male CL to 16, female to 17.

Previous geographic and depth reports. - Worldwide at lower latitudes (but see remarks), mesopelagic (Springer \& Bullis, 1956; Hopkins \& Lancraft, 1984; Chace, 1986; Hopkins et al., 1989).

Remarks. - Until recently, A. curtirostris was considered to be a single cosmopolitan species. Hanamura (1983) described $A$. brevicarinata from the eastern Pacific, and distinguished it from A. curtirostris. Chace (1986) and Hendrickx \& Estrada-Navarrete (1996) also distinguished between the two species. The principal differences between the species are the length of the carina extending posteriorly from the branchiostegal spine: barely extending beyond the spine in $A$. brevicarinata versus reaching to or near the hepatic sulcus in $A$. curtirostris; and the shape and ventral teeth of the rostrum: narrowly triangular, with 1-2 ventral teeth in $A$. brevicarinata; or triangular to almost rectangular, with only one ventral tooth, in $A$. curtirostris. Hendrickx \& Wicksten (2004) reported that $A$. brevicarinata seems primarily to be a benthic or nearbenthic species ranging in the eastern Pacific as far north as the Guaymas Basin and off Bahía Magdalena, Mexico.

Acanthephyra curtirostris has been reported in the eastern Pacific, mostly from California northward (Butler, 1980; Hendrickx \& Estrada Navarrete, 1996;
Wicksten, 2002). Hendrickx \& Wicksten (2004) reported $A$. curtirostris off Dowd Seamount $\left(13^{\circ} 28^{\prime} \mathrm{N}, 73^{\circ} 93^{\circ} 50^{\prime \prime} \mathrm{W}\right)$ and the Panama Basin $\left(5^{\circ} 09.8^{\prime} \mathrm{N}, 81^{\circ} 41.2^{\prime} \mathrm{W}\right)$. We also examined specimens of this species collected off northern California (SIO stations MV66- $49,40^{\circ} 36^{\prime} \mathrm{N}, 125^{\circ} 45^{\prime} \mathrm{W}$ to $39^{\circ} 0^{\prime} \mathrm{N}$, $126^{\circ} 9^{\prime} \mathrm{W}, 727 \mathrm{~m}$, two males; MV66-II-7, $38^{\circ} 24.0^{\prime} \mathrm{N}, 124^{\circ} 6.6^{\prime} \mathrm{W}$ to $41.0^{\circ} \mathrm{N}, 124^{\circ} 32.5^{\prime} \mathrm{W}$, $550 \mathrm{~m}$, three males, five females) and off the western coast of Baja California, Mexico (SIO station MV66-I-26, $29^{\circ} 16^{\prime} \mathrm{N}, 117^{\circ} 22^{\prime} \mathrm{W}$, $5900 \mathrm{~m}$, one male, one juvenile). All of these specimens, as do the specimens from the Gulf of Mexico, have a prominent carina that extends from the branchiostegal spine to the hepatic carina, and all have one ventral rostral tooth. We saw no morphological differences between the specimens from the Gulf of Mexico and Pacific. The smallest specimens (CL of $7 \mathrm{~mm}$ or less) generally had the shortest rostrums, reaching to the end of the first segment of the antennular peduncle and not to its end or beyond it.

\section{Acanthephyra eximia Smith, 1884}

Material examined. - 65 specimens from 26 stations, throughout Gulf; also 33 specimens from 10 Caribbean stations.

Depth range. $-878-1829 \mathrm{~m}$.

Size. - Male CL to 24.5, female to 40.

Previous geographic and depth reports.- Tropical and temperate coasts of the world, including Gulf of Mexico; probably on or near the bottom at $200-4700 \mathrm{~m}$ or deeper (Chace, 1940, 1947, 1986; Springer \& Bullis, 1956; Thompson, 1963; Crosnier \& Forest, 1973; Kensley, 1981; Hanamura, 1983; Takeda \& Okutani, 1983; Baba et al., 1986; Hendrickx \& Estrada-Navarete, 1989; Wicksten, 2002; Cardoso \& Young, 2005).

Remarks. -All of the specimens taken in the Gulf of Mexico were collected with benthic sampling gear, not midwater trawls. We agree with Chace (1986) that this species is primarily benthic, living on or near the sea floor.

We compared our specimens of $A$. eximia from the Gulf of Mexico with eight 
specimens of $A$. eximia taken in the eastern Pacific (SIO catalog numbers C 5675, C 5676 , C 5677, C5679). We found no morphological differences between the specimens. We noted that male $A$. eximia tended to have relatively longer rostrums (exceeding the end of the scaphocerite) than females.

\section{Acanthephyra pelagica (Risso, 1816)}

Material examined. - Eight specimens from four stations as follows:

NE Gulf: sta. 66A5-5, $28^{\circ} 44.5^{\prime} \mathrm{N}$, $87^{\circ} 46^{\prime} \mathrm{W}, 0-1000 \mathrm{~m}$, trawl, 14 April 1966, 1 specimen (sex not determined), TCWC 28769 .

SW Gulf: sta. $69 \mathrm{~A} 13-7,24^{\circ} 53{ }^{\prime} \mathrm{N}, 90^{\circ} 45^{\prime} \mathrm{W}$, 0-2500 m, trawl, 5 Oct. 1969, 1 male, TCWC 2- 6632; 71A8-29, $23^{\circ} 54.7$ ’N, 96 ${ }^{\circ} 59.9^{\prime} \mathrm{W}, 0-937$ m, 4 Aug. 1971, 3 males, 1 female, 1 juvenile, TCWC 2-6633; 72A13-23, 23ํำ $17.4^{\prime} \mathrm{N}, 97^{\circ} 2^{\prime} \mathrm{W}$, $1006-1080 \mathrm{~m}, 12$ July 1972,1 female, TCWC $2-8715$. These are the first records of the species from the Gulf of Mexico.

Depth range. - 937-2500 m. mesospelagic and bathypelagic.

Size. - Male CL to 28, female to 20.

Previous geographic and depth reports. - Eastern and western North Atlantic north of $13^{\circ} \mathrm{N}$, Mediterranean Sea, Bermuda and Bahamas; off Uruguay, southeastern Atlantic, Indo-Pacific, off Chile and subantarctic waters of southern Pacific, mesopelagic (Chace, 1940, 1947, 1986; Crosnier \& Forest, 1973; Kensley, 1981; Takeda \& Hatanaka, 1984; Wasmer, 1986; Hendrickx \& Estrada-Navarrete, 1989; Kensley, 2006). See Wasmer (1993) for a more complete list of locations at which this species has been collected.

Remarks. - Our specimens of A. pelagica agree with the key features as given by Chace $(1940,1986)$. Chace (1940) noted that the most common number of dorsolateral spines of the telson was nine, followed by 10 , eight and seven. "Six, seven, twelve, and thirteen spines occur so rarely that such a condition might well be regarded as abnormal". Where the telson was not completely broken, in our specimens there were at least
9 or 10 dorsolateral spines. One specimen each had 14 or 15 spines. The largest specimens had the most spines.

\section{Acanthephyra purpurea A. Milne-Edwards,} 1881

Material examined. - 184 specimens from 73 stations, throughout Gulf; also 32 specimens from 16 Caribbean stations.

Depth. - 300- $3292 \mathrm{~m}$ but usually above $1500 \mathrm{~m}$, mesopelagic.

Size. - Male CL to 18 , female to 21.

Previous geographic and depth reports. - North Atlantic to Caribbean Sea, 900-1800 m (Chace, 1940, 1986; Springer \& Bullis, 1956; Takeda \& Okutani, 1983; Hopkins \& Lancraft, 1984; Hopkins et al., 1989). (Reports of this species from other oceans probably refer to species of the $A$. purpurea species group, such as A. quadrispinosa of the Indo-Pacific region).

Notes on depth distribution. Generally, the largest sized specimens were found at stations sampling deeper than 1000 m. Our sampling did not permit us to discern patterns of vertical migration, as was found for this species in the northeastern Atlantic (Foxton, 1970) and suggested for the species in the northeastern Gulf of Mexico (Hopkins et al., 1989).

\section{Acanthephyra stylorostratis (Bate, 1888)}

Material examined. - 77 specimens from 28 stations, throughout Gulf; also NW Caribbean Sea, sta. $70 A 10-13,16^{\circ} 30.7^{\prime} \mathrm{N}$, $84^{\circ} 41.5^{\prime} \mathrm{W}$, trawl, $1875 \mathrm{~m}$, 9 July 1970,1 male, TCWC 2-6642; northern Caribbean, 70A10-51, $17^{\circ} 17.1^{\prime} \mathrm{N}, 7^{\circ} 50.6^{\prime} \mathrm{W}$, trawl, 1097 m, 26 July 1970, 1 specimen, (sex not determined, abdomen missing), TCWC 2-8201. These are the first records of the species from the Caribbean Sea.

Depth. - 750-3548 m, lower mesopelagic and bathypelagic. Most specimens were taken at stations at which the maximum sampling depth was $1500 \mathrm{~m}$ or more.

Size. - Male CL to 13 , female to 10.5 .

Previous geographic and depth reports. -North Atlantic, including Gulf of Mexico, 
southwestern Brazil, off South Africa, central South Pacific, mesopelagic (Springer \& Bullis, 1956; Crosnier \& Forest, 1973; Hopkins \& Lancraft, 1984; Chace, 1986; Hopkins et al., 1989; Cardoso \& Young, 2005).

\section{Genus Ephyrina}

Ephyrina benedicti Smith, 1885

Material examined. - 12 specimens from 11 stations, NW and SW Gulf; also the following:

Straits of Yucatán: sta. 65A9-13, $20^{\circ} 53$ 'N, $85^{\circ} 35^{\prime} \mathrm{W}, 0-2600 \mathrm{~m}$, midwater trawl, 9-10 July1965, 1 specimen (sex not determined), TCWC 2-8325.

Caribbean Sea: Oregon station 3570, off Nicaragua; $14^{\circ} 8^{\prime} \mathrm{N}, 81^{\circ} 55^{\prime} \mathrm{W}$, trawl, 21 May 1962, 2 specimens (sex not determined), TCWC 2-758. These are the first reports of this species from the Caribbean Sea.

Depth. - 1199-3285 m, lower mesopelagic and bathypelagic. All specimens came from stations at which the maximum depth was at least $1199 \mathrm{~m}$.

Size. - Male CL to 26, female to 24 .

Previous geographic and depth records. - Western North Atlantic and eastern North and equatorial Atlantic, northeastern Gulf of Mexico, southwestern Brazil, Japan and northeastern Philippine Sea, mesopelagic and bathypelagic (Crosnier \& Forest, 1973; Hopkins \& Lancraft, 1984; Chace, 1986; Hopkins et al., 1989; Cardoso \& Young, 2005). See Crosnier \& Forest (1973) for a more complete list of references.

Remarks. - Springer \& Bullis (1956) and Bullis \& Thomspon (1965) reported $E$. hoskynii from the Gulf of Mexico. We suspect that these records are a misidentification either of $E$. benedicti or E. ombango, but have not been able to re-examine the specimens on which these records are based.

Ephyrina benedicti was reported previously only in the northeastern Gulf of Mexico (Hopkins \& Lancraft, 1984; Hopkins et al., 1989). Our records suggest that it is uncommon but widespread in the Gulf.

\section{Ephyrina ombango Crosnier \& Forest, 1973}

Material examined. - Four specimens from four stations, NE, NW and SW Gulf; also one damaged Caribbean specimen from one station..

Depth. - 937-1875 m, mesopelagic.

Size. - Male CL to 24, female 17.

Previous geographic and depth reports.

- Eastern and western Pacific, western North Atlantic, Gulf of Mexico, Caribbean Sea, Indian Ocean, eastern north and south Atlantic, mesopelagic (Crosnier \& Forest, 1973; Chace, 1986; Hopkins et al., 1989).

Remarks. - Crosnier \& Forest (1973) included a male specimen taken by the Alaminos in their type material of Ephyrina ombango. The station was listed incorrectly as $68 \mathrm{~A} 7-138$. The correct designation is 68A7-13B.

\section{Genus Heterogenys}

Heterogenys microphthalma (Smith, 1885)

Material examined. - 13 specimens from 10 stations, as follows:

NE Gulf: sta. $68 \mathrm{~A} 7-4 \mathrm{~A}, 25^{\circ} 20^{\prime} \mathrm{N}, 86^{\circ}$ 7’W, 3237 m, skimmer, 28 July 1968, 1 male, TCWC 2-6626; 68A7-4E, $25^{\circ} 24.8^{\prime} \mathrm{N}, 86^{\circ} 16.5$ ' W, 3255 m, skimmer, 29-30 July 1968, 1 male, 1 female, TCWC 2-6627; 69A13-29, 25 $30^{\prime} \mathrm{N}, 86^{\circ} 09^{\prime} \mathrm{W}, 3230 \mathrm{~m}$, skimmer, 12 Oct. 1969, 1 female, TCWC 2-6630; 69A13-37, $26^{\circ} 55^{\prime} \mathrm{N}, 86^{\circ} 48^{\prime} \mathrm{W}, 3001 \mathrm{~m}$, skimmer, $13-14$ Oct. 1969, 1 specimen (sex not determined),

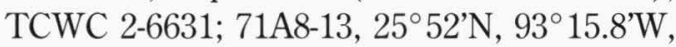
$3267 \mathrm{~m}$, trawl, 1 male, 2 females, TCWC 28433.

SW Gulf: sta. 68 A3-5B, $23^{\circ} 44^{\prime} \mathrm{N}$, $92^{\circ} 36$ 'W, $3840 \mathrm{~m}$, skimmer, 18 March 1968 , 1 specimen (sex not determined), TCWC 2-

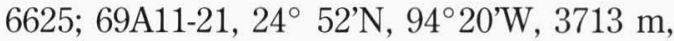
skimmer, 12 Aug. 1969, 1 specimen (sex not determined), TCWC 2-6628; 69A11-52, $20^{\circ} 04^{\prime} \mathrm{N}, 95^{\circ} 07^{\prime} \mathrm{W}, 2805 \mathrm{~m}$, skimmer, 18 Aug. 1969, 1 specimen (abdomen missing), TCWC 2-6629; JSSD-3, 24 ${ }^{\circ} 52.8^{\prime} \mathrm{N}$, $90^{\circ} 17.9^{\prime} \mathrm{W}, 3600 \mathrm{~m}$, trawl, 7 Aug. 2002, 1 specimen (sex not determined), UNAM. 
SE Gulf: sta. $65 \mathrm{~A} 9-17,23^{\circ} 43^{\prime} \mathrm{N}, 85^{\circ} 51^{\prime} \mathrm{W}$, 0-2800 m, trawl, 1 female, TCWC 2-8769. These are the first records of the species from the Gulf of Mexico.

Depth. - 2800-3840 m.

Size. - Male and female CL to 17 .

Previous geographic and depth reports. - Nearly worldwide in temperate and tropical seas, 2000-4792 m, probably benthic (Crosnier \& Forest, 1973, as Acanthephyra microphthalma; Chace, 1986).

Remarks. - All specimens of $H$. microphthalma in the collections of the TCWC were taken with benthic sampling gear.

\section{Genus Hymenodora}

Hymenodora glacialis (Buchholtz, 1874)

Material examined. - Central Gulf of Mexico, sta. $69 \mathrm{~A} 13-7,24^{\circ} 53^{\prime} \mathrm{N}, 90^{\circ} 45^{\prime} \mathrm{W}, 0-$ $2500 \mathrm{~m}$, (bottom depth $3569 \mathrm{~m}$ ), midwater trawl, 5 Oct. 1969, 1 specimen (sex not determined), TCWC 2-6647.

Depth. - To $2500 \mathrm{~m}$.

Size. - CL 10, sex not determined.

Previous geographic and depth reports. - Arctic region southward in both eastern and western North Atlantic, Gulf of Mexico, South Atlantic, Arabian Sea, southern Indian Ocean, eastern Pacific; mesopelagic and bathypelagic (Springer \& Bullis, 1956; Chace, 1986, Hendrickx \& EstradaNavarrete, 1989, 1996; Wasmer, 1993; Wicksten, 2002). See Wasmer (1993) for a detailed account of geographic locations.

Remarks. - Apparently the dentition on the dorsal midline of the carapace and rostrum is variable in this species. Sivertsen \& Holthuis (1956, fig. 2) showed one specimen with four dorsal teeth and another with only two teeth. Our specimen has only one small trace of a tooth on the mid-dorsal surface of the carapace posterior to the orbit.

\section{Hymenodora gracilis Smith, 1886}

No material examined. The species was not collected during cruises of the Alaminos.

Previous geographic and depth reports.
- Reported in the NE Gulf of Mexico, $28^{\circ} 28^{\prime} \mathrm{N}, 87^{\circ} 18^{\prime} \mathrm{W}, 0-1426 \mathrm{~m}$, Oregon sta. 1028, (Springer \& Bullis, 1956), also Atlantic from Greenland to off Congo, southern Indian Ocean, and eastern Pacific, to $5300 \mathrm{~m}$ (Chace, 1947, 1986; Crosnier \& Forest, 1973; Hanamura, 1983; Hendrickx \& EstradaNavarrete, 1989, 1996; Wasmer, 1993; Allen \& Butler, 1994; Wicksten, 2002). See Wasmer (1993) for a detailed account of geographic reports.

\section{Hymenodora, unidentified species}

Material examined. - Central Gulf of

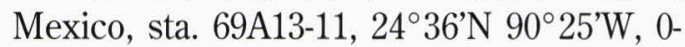
$2700 \mathrm{~m}$, (bottom depth $3687 \mathrm{~m}$ ), midwater trawl, 6 Oct. 1969, 1 male, TCWC 2-6651; S. Caribbean Sea, 70A10-48, $14^{\circ} 129.5^{\prime} \mathrm{N}$, $74^{\circ} 24.8^{\prime} \mathrm{W}, 4151 \mathrm{~m}$, benthic trawl, 24 July 1970, 1 female, TCWC 2-6650.

Depth. - To $4151 \mathrm{~m}$.

Size. - Male CL 26, female 14.

Remarks. - These two specimens lack a dorsal carina and spines on the abdomen. The telson has a sulcate dorsal surface and four pairs of dorsolateral spines. The eyes are small and born on long eyestalks. The dorsal surface of the carina of the carapace is most peculiar. In the male, there are 10 spinules on the dorsal carina; in the female, there are 20. Both specimens are badly smashed and cannot be identified with confidence to any species of Hymenodora known from the northwestern Atlantic region.

\section{Genus Janicella}

Janicella spinicauda (A. Milne-Edwards, 1883)

Material examined. - 67 specimens from 18 stations, throughout Gulf; no Caribbean specimens.

Depth. - 300-1500 m but usually above $1000 \mathrm{~m}$, mesopelagic.

Size. - Male CL to 8, female to 10 .

Previous geographic and depth records. - Widespread in tropical seas of the world except in eastern Pacific off the Americas, mesopelagic (Springer \& Bullis, 1956, Bullis 
\& Thompson, 1956, Crosnier \& Forest, 1973, as Oplophorus spinicauda; Chace, 1986; Hopkins et al., 1989; Cardoso \& Young, 2005).

Remarks. - Hopkins et al. (1989) suggested that the species might migrate to the epipelagic zone at night.

\section{Genus Meningodora}

\section{Meningodora marptocheles (Chace, 1940)}

Material examined. - Six specimens from five stations, NW and SE Gulf; also NW Caribbean Sea, sta. 65A9-10, $19^{\circ} 58^{\prime} \mathrm{N}$, $85^{\circ} 14^{\prime} \mathrm{W}, 0-2400 \mathrm{~m}$, midwater net, 28 July 1965, 1 specimen (sex undetermined, pleopods missing), TCWC $2-8814$. This is the first record for this species in the Caribbean Sea.

Size. - Male CL 10, female to 14.

Previous geographic and depth reports. -Western North Atlantic off Bermuda and Bahamas, Banda Sea, Indonesia, mesopelagic and bathypelagic (Hopkins \& Lancraft, 1984; Chace, 1940, 1986).

Depth. - 800-3477 m, mesopelagic and bathypelagic.

Remarks. - This species previously was reported in the northeastern Gulf (Hopkins \& Lancraft, 1984). Our records suggest that it is uncommon but widespread in the Gulf.

\section{Meningodora mollis Smith, 1882}

Material examined. - Five specimens from five stations, NE and SW Gulf.

Depth. - 1326-3740 m, mesopelagic and bathypelagic

Size. -Male CL to 23, female to 21.

Previous geographic and depth records. - Western and eastern North and South Atlantic including Gulf of Mexico, off South and eastern Africa, Indian Ocean, South China Sea, eastern Pacific; mesopelagic and bathypelagic (Springer \& Bullis, 1956; Crosnier \& Forest, 1973; Hopkins \& Lancraft, 1984; Chace, 1986; Hopkins et al., 1989; Hendrickx \& Estrada-Navarrete, 1989, 1996; Wicksten, 2002).

Remarks. - Springer \& Bullis (1956),
Hopkins \& Lancraft (1984) and Hopkins et al. (1989) also reported this species from the northeastern Gulf.

A specimen from station $68 \mathrm{~A} 3-4 \mathrm{C}$ $\left(23^{\circ} 36^{\prime} \mathrm{N}, 93^{\circ} 57^{\prime} \mathrm{N}, 0-3740 \mathrm{~m}\right.$, skimmer) has eight tiny spinules on the mid-dorsal carina of the carapace posterior to the rostrum. We also examined a specimen from the Caribbean Sea (station $70 \mathrm{~A} 10-43,13^{\circ} 13.2^{\prime} \mathrm{N}$, $69^{\circ} 43.8^{\prime} \mathrm{W}, 3005 \mathrm{~m}$ ) that has 14 small spinules as well as four dorsal rostral teeth. Both of these specimens had been provisionally identified as species of Hymenodora by one of us (LHP), but the size, soft exoskeleton and shape of the carapace and rostrum more closely resemble those of $M$. mollis. Chace (1986: 49) stated that species of Meningodora have a carapace "not denticulate on posterior $3 / 4$ of length" but on p. 49 said that they have a carapace that is "not denticulate dorsally". However, Hendrickx \& Estrada-Navarrete (1996) said that in $M$. mollis, the dorsal carina of the carapace is without teeth "on the last posterior threequarters". Most specimens of $M$. mollis are badly smashed after being collected in nets. It may be very difficult to determine if there is regional or individual variation in the number of spinules of the mid-dorsal carina.

Meningodora vesca (Smith, 1886)

No material examined. The species was not collected during the cruises of the Alaminos.

Previous geographic and depth reports. - Reported in the NE Gulf of Mexico, vicinity of $27^{\circ} \mathrm{N} 86^{\circ} \mathrm{W}$ (Hopkins \& Lancraft, 1984; Hopkins et al., 1989), also North, eastern and South Atlantic; Bay of Bengal, Philippines, Indonesia, mesopelagic (Chace, 1986).

\section{Genus Notostomus}

Notostomus elegans A. Milne-Edwards, 1881

Material examined. - SW Gulf, sta. $69 \mathrm{~A} 13-7,24^{\circ} 53^{\prime} \mathrm{N}, 90^{\circ} 45^{\prime} \mathrm{W}, 0-1600 \mathrm{~m}$, midwater trawl, 5 Oct. 1969, 1 juvenile, TCWC 2 6664; NW Caribbean, 70A10-13, 16 $30.7^{\circ} \mathrm{N}$, 
$84^{\circ} 41.5^{\prime} \mathrm{W}, 1875 \mathrm{~m}$, trawl, 9 July 1970,1 female, TCWC 2-6665; central Caribbean, $70 \mathrm{~A} 10-48,14^{\circ} 29.5^{\prime} \mathrm{N}, 74^{\circ} 24.8^{\prime} \mathrm{W}, 4151 \mathrm{~m}$, trawl, 24 July 1970, 1 male, TCWC 2-6666. These are the first records of the species from the Caribbean Sea.

Depth. - To $1600 \mathrm{~m}$.

Size. - Male to 45, female to 14.5 (based on Caribbean specimens).

Previous geographic and depth records. - Western and eastern North Atlantic including Gulf of Mexico, southwestern Brazil, Philippines, Indonesia, eastern tropical Pacific, mesopelagic (Chace, 1947, 1986; Crosnier \& Forest, 1973; Hopkins \& Lancraft, 1984; Méndez, 1981, as N. westergreni; Cardoso \& Young, 2005).

Remarks. - Hopkins et al. (1989) reported both Notostomus elegans and $N$. westergreni Faxon, 1893 from the northeastern Gulf of Mexico. Chace (1986) synonymized these two species. The type material of $N$. westergreni came from the eastern Pacific. Further work may indicate that these should be designated as separate species.

Notostomus gibbosus A. Milne-Edwards, 1881

Material examined. - 31 specimens from 21 stations, throughout Gulf; also five specimens from five Caribbean stations.

Depth. - 500-2736 m, mostly mesopelagic.

Size. - Male CL to 35, female to 44 .

Previous geographic and depth records. - Western and eastern North and equatorial Atlantic including Gulf of Mexico and Caribbean, off east coast of Africa, Indonesia, Marquesas Islands, mesopelagic (Chace, 1940, 1986; Crosnier \& Forest, 1973; Takeda \& Okutani, 1983; Hopkins \& Lancraft, 1984, as Notostomus perlatus). See Crosnier \& Forest (1973) for a more detailed account of geographical locations.

Remarks. - Notostomus gibbosus was taken in pelagic samples at midwater stations where the maximum sampling depths averaged $1108 \mathrm{~m}$ above the sea floor, thus confirming the mesopelagic status of this species.

\section{Genus Oplophorus}

Oplophorus gracilirostris A. MilneEdwards, 1881

Material examined. - 45 specimens from 26 stations, throughout Gulf; also 30 specimens from 14 Caribbean stations.

Depth. - 300-2800 m but mostly mesopelagic, above $1000 \mathrm{~m}$.

Size. - Both male and female CL to 16.5.

Previous geographic and depth records. - Gulf of Mexico, Bahamas, Caribbean Sea, southwestern Brazil, southwestern Africa, Indian Ocean, Indonesia, Philippines, southern Japan, Fiji Islands, Hawaii, mesopelagic (Chace, 1947, 1986; Bullis \& Thomspon, 1965; Kensley, 1968; Takeda \& Okutani, 1983; Cardoso \& Young, 2005).

Remarks. - Oplophorus gracilirostris was taken in pelagic samples where the maximum sampling depth averaged $1105 \mathrm{~m}$ above the bottom, thus verifying the mesopelagic status of this species. Hopkins et al. (1989) reported that the species was most abundant at 450-600 $\mathrm{m}$.

\section{Oplophorus spinosus (Brullé, 1839)}

Material examined. - Two specimens as follows: SW Gulf, sta. 71A8-58, $19^{\circ} 22^{\prime} \mathrm{N}$, 95 $53^{\prime} \mathrm{W}, 0-300 \mathrm{~m}$, midwater trawl, 1 August 1971, 1 female, TCWC 2-7369; southern Caribbean Sea, Oregon $4846,11^{\circ} 6.8^{\prime} \mathrm{N}$, 74²3.6’W, 92 m, trawl, 17 May 1964, 1 ovigerous female TCWC 2-7280.

Depth. $-300 \mathrm{~m}$.

Size. - Female, CL 9.

Previous geographic and depth records. - Western and eastern subtropical North Atlantic, central South Atlantic, southwestern Brazil, Indian Ocean, southern Japan, off Hawaii, seamounts west of North America, northeast of Eastern Island, mesopelagic (Hanamura, 1983; Abele \& Kim, 1986; Chace, 1986; Kensley et al., 1987; Hendrickx \& Estrada-Navarrete, 1989; Cardoso \& Young, 2005).

Remarks. - Pequegnat (1971) reported Oplophorus spinosus from the Gulf of Mexico, but further examination revealed 
that the specimens were juveniles of $O$. gracilirostris. Hopkins \& Lancraft (1984) and Hopkins et al. (1989) reported O. spinosus from the northeastern Gulf of Mexico. We were unable to re-examine their specimens to confirm their identity. We compared our specimens from the Gulf of Mexico and Caribbean Sea. They agree in lacking the tooth on the posterior ventral margin of the carapace, and having the antennal scale armed with teeth on the lateral margin and a distinct barb on the mesial margin near the apex, as described by Chace (1986).

\section{Genus Systellaspis}

\section{Systellaspis cristata (Faxon, 1893)}

Material examined. - NW Gulf, sta. 72A13-7, $27^{\circ} 13^{\prime} \mathrm{N}, 95^{\circ} 16^{\prime} \mathrm{W}, 1207 \mathrm{~m}$, trawl, 8 July 1972, 1 specimen (sex not determined, pleopods missing), TCWC 2-8709.

Depth. - To $1207 \mathrm{~m}$.

Size. - Female CL18.

Previous geographic and depth records. - Gulf of Mexico, eastern Atlantic from Bay of Biscay to Angola, Indian Ocean, Philippines, Indonesia, eastern Pacific, mesopelagic (Crosnier \& Forest, 1973; Hanamura, 1983; Hopkins et al., 1989; Hendrickx \& Estrada-Navarrete, 1996; Chace, 1986; Wicksten, 2002).

Remarks. - The species is known from the Gulf of Mexico from only two other records, Oregon sta. $841,28^{\circ} 58^{\prime} \mathrm{N}, 88^{\circ} 00^{\prime} \mathrm{W}$, 0-1701 m (Springer \& Bullis, 1956) and in the vicinity of $27^{\circ} \mathrm{N} 86^{\circ} \mathrm{W}$ (Hopkins et al., 1989).

\section{Systellaspis debilis (A. Milne-Edwards, 1881)}

Material examined. - 177 specimens from 67 stations, throughout Gulf; also 26 specimens from 12 Caribbean stations.

Depth. - 300-3255 m but usually at 1000 $\mathrm{m}$ or less.

Size. - Male CL to 14 , female to 15.

Previous geographic and depth records. - Western Atlantic from south of Greenland to Gulf of Mexico, Bahamas, Caribbean Sea, southwestern Brazil, eastern Atlantic from
Faeroe Islands to Angola, South Africa, Indian Ocean, Philippines, Indonesia, Hawaii, mesopelagic (Bullis \& Thompson, 1965; Crosnier \& Forest, 1973; Hopkins \& Lancraft, 1984; Chace, 1986; Hopkins et al., 1989; Baba et al., 1986; Hendrickx \& Estrada-Navarrete, 1989; Wasmer, 1993; Allen \& Butler, 1994; Wicksten, 2002; Cardoso \& Young, 2005). See Wasmer (1993) for a more detailed list of geographic locations.

Remarks. - Of the 67 stations in the Gulf of Mexico where $S$. debilis occurred and the 73 stations where Acanthephyra purpurea occurred, only 26 stations showed concurrent occurrences of the two species. This would suggest that there might be habitat differences that separate the two most abundant oplophorid species in the Gulf of Mexico. Hopkins et al. (1989) found evidence that the species migrates vertically daily.

\section{Systellaspis pellucida (Filhol, 1885)}

Material examined. - 102 specimens from nine stations, NE, NW and SE Gulf; of these, 83 specimens came from a single station, $71 \mathrm{~A} 8-71\left(19^{\circ} 37.5^{\prime} \mathrm{N}, 92^{\circ} 20.5^{\prime} \mathrm{W}, 220-342\right.$ m, skimmer, 14 Aug. 1971). Also 30 specimens from seven Caribbean stations.

Depth. - 274-1200 m.

Size. - Both male and female CL to 17 .

Previous geographic and depth records. - Gulf of Mexico, Bahamas, West Indies, southwestern Brazil and off northwest Africa from Morocco to Gabon, western Indian Ocean, South China Sea, Philippines, Indonesia, usually found on or near bottom in 291-3292 m, commonly between 300 and 600 m (Chace, 1947, 1986; Thompson, 1963, as S. affinis; Crosnier \& Forest, 1973; Springer \& Bullis, 1956; Cardoso \& Young, 2005).

Remarks. - Systellaspis pellucida always was taken with benthic sampling gear except for one midwater station that accidentally hit bottom. Specimens from the Gulf of Mexico were most commonly found between 300 and $600 \mathrm{~m}$. Bullis \& Thompson 
(1965) reported this species from a depth of $3292 \mathrm{~m}$ at Oregon sta. $2201\left(25^{\circ} 30^{\prime} \mathrm{N}\right.$, $92^{\circ} 15^{\prime} \mathrm{W}$, central Gulf of Mexico). This depth record is questionable because all other depths reported for this species range from 274 to $1170 \mathrm{~m}$.

Systellaspis pellucida has been reported from the "West Indies". We examined 30 specimens taken by trawl from seven stations in the western and southern Caribbean (stations $70 \mathrm{~A} 10-15,16^{\circ} 99^{\prime} \mathrm{N}, 8^{\circ} 37.1^{\prime} \mathrm{N}, 399-$ $531 \mathrm{~m}, 10$ July 1970,1 specimen, TCWC 2 8224; 70A10-20, $16^{\circ} 24^{\prime} \mathrm{N}, 84^{\circ} 37^{\prime} \mathrm{W}, 1079-1170$ m, 11 July 1970, 2 specimens, TCWC 2-8825; 70A10-25, $16^{\circ} 43^{\prime} \mathrm{N}, 82^{\circ} 38^{\prime} \mathrm{W}, 430-613 \mathrm{~m}, 12$ July 1970, 17 specimens, TCWC 2-8266; 70A10-35, $11^{\circ} 29^{\prime} \mathrm{N}, 73^{\circ} 33^{\prime} \mathrm{W}, 476$ m, 17 July 1970, 6 specimens, TCWC 2-8307; Oregon $4417,11^{\circ} 46^{\prime} \mathrm{N}, 69^{\circ} 15^{\prime \prime} \mathrm{W}, 439 \mathrm{~m}, 4$ Oct. 1963 , 1 specimen, TCWC 2-7753; Oregon II 10812, $7^{\circ} 38^{\prime} \mathrm{N}, 53^{\circ} 32^{\prime} \mathrm{W}, 677 \mathrm{~m}, 22$ Nov. 1969,2 specimens, TCWC 2-7728; Oregon II 11242, $10^{\circ} 10^{\prime} \mathrm{N}, 76^{\circ} 14^{\prime} \mathrm{W}, 1098 \mathrm{~m}, 1$ specimen, TCWC 2-7731).

Cardoso \& Young (2005) stated that, prior to their report, S. pellucida in the Western Atlantic was "previously recorded only from Central America”. This is not correct. Bullis \& Thompson (1965) reported the species from the Gulf of Mexico, which is considered to be located off North America.

\section{Discussion}

We examined 1,404 specimens $(1,001$ from the Gulf of Mexico and 403 from the Caribbean Sea) from 193 stations (130 from the Gulf of Mexico and 63 from the Caribbean Sea). We believe that the species present in the TCWC and their abundances are likely to be reasonably accurate representations of the oplophorids in the Gulf of Mexico. With such available information, we can suggest a few directions for further study.

We found little difference in the oplophorid species by geographic location in the Gulf of Mexico. Benthic decapods of the slopes and abyssal plain in the Gulf of
Mexico also tend to occur throughout the Gulf according to depth, but certain species occur only in the eastern Gulf (Wicksten \& Packard, 2005). We expected to see some change in species composition along the path of the Loop Current, in the eastern Gulf of Mexico, but found no evidence for such a change. Such a pattern might be detected by quantitative sampling with closing nets.

On the whole, the oplophorid species of the Gulf of Mexico are widely distributed in the greater western Atlantic and other world oceans. We agree with Hopkins et al. (1989), who stated that the midwater decapod assemblage of the northeastern Gulf of Mexico was typical of a subtropical-tropical gyre, with close affinity to the fauna of the North Atlantic. Species reported from the North Atlantic that are not present in our collections include Acanthephyra kingsleyi Bate, 1888, Meningodora compsa (Chace, 1940), Ephyrina bifida Stephensen, 1923, and Systellaspis braueri (Balss, 1914) (Crosnier \& Forest, 1973; Chace, 1986). There are seven species represented by less than 10 specimens in our collections: Acanthephyra pelagica, Hymenodora glacialis, Meningodora marptocheles, Meningodora mollis, Notostomus elegans, Oplophorus spinosus and Systellaspis cristata. We have no specimens of Hymenodora gracilis or Meningodora vesca, although these species have been reported in the area (Springer \& Bullis, 1956; Hopkins \& Lancraft, 1984; Hopkins et $a l ., 1989)$. The reasons why certain species are absent or rare in the Gulf of Mexico remain unknown, but regional patterns of circulation or water temperature may be involved.

We compared the species reported or in our collections from the Gulf of Mexico with those collected in the Caribbean. Of 25 species taken in the Gulf, fifteen also are known from the Caribbean. We suspect that some of the differences in species composition are due to sampling methods. The Oregon, Oregon II and Alaminos collected by skimmers or benthic trawls, not midwater trawls, in the Caribbean. The Oregon and 
Oregon II did not collect samples on the abyssal plains. Smaller carideans such as Janicella spinicauda might have escaped from a trawl with a larger mesh size.

In our experience, specimens of Hymenodora can be among the most common oplophorids collected in temperate midwater samples. It seems unusual that so few have been collected in the Gulf of Mexico and Caribbean Sea. Hopkins et al. (1989) also commented on the absence of Hymenodora spp. among their collections. It is possible that there is a gap in the northsouth range of these shrimp in the tropical western Atlantic, or perhaps these shrimps usually are present in the mid-Atlantic and not in the semi-enclosed basins. It is possible that species of Hymenodora occupy greater depths in the Gulf of Mexico and Caribbean than in more temperate or polar seas, and therefore were not caught because of less sampling effort. Our unidentified Hymenodora sp. may represent a poorly sampled bathypelagic species.

There are some peculiar differences between the oplophorid fauna of the Gulf of Mexico and Caribbean Sea and that of the warm-temperate to tropical eastern Pacific. Chace (1986), Hendrickx \& EstradaNavarrete (1996) and Wicksten (2002) do not report any species of Heterogenys, Janicella or Ephyrina in the eastern Pacific. Systellaspis debilis has not been reported off the western coast of Mexico, although it occurs in the northeastern Pacific (Wicksten, 2002). Species of Notostomus occur in the northeastern Pacific and off Ecuador and Perú, but have not been reported in the tropical areas between these locations (Méndez, 1981; Wicksten, 2002). Acanthephyra armata has not been reported in the eastern Pacific. All of the oplophorid genera reported in the eastern Pacific also occur in the Gulf of Mexico and adjacent oceanic areas (Chace, 1986). The deep-sea biota of the tropical eastern Pacific remains poorly studied, so lack of sampling may account for the seeming absence of certain taxa.

\section{Acknowledgments}

We are grateful for the measurements and morphological comparisons of Acanthephyra eximia done by Kristin Hamann as part of an undergraduate research project at Texas A\&M University. Annie Townsend, Scripps Institution of Oceanography, sent specimens for examination. We thank an anonymous reviewer for helpful suggestions regarding the manuscript.

\section{Literature Cited}

Abele, L., \& Kim, W., 1986. An illustrated guide to the marine decapod crustaceans of Florida. Florida Department of Environmental Regulation Technical Series, 8: 1-326.

Allen, J. \& Butler, T., 1994. The Caridea (Decapoda) collected by the Mid-Pacific Mountains Expedition, 1968. Pacific Science, 48: 410-445.

Baba. K., Hayashi, K. \& Toriyama, M., 1986. Decapod crustaceans from continental shelf and slope around Japan. Tosho Printing, Tokyo, $336 \mathrm{pp}$.

Balss, H. , 1914. Diagnosen neuer Macruren der Valdiviaexpedition . Zoologisher Anzeiger, 44: 592-599.

Bate, C.S., 1888. Report on the Crustacea Macrura collected by the "Challenger" during the years 1873-76. Report on the scientific results of the voyage of the H.M.S. "Challenger" during the years 1873-76, 24: 1-942.

Brullé, M., 1839. Crustacés. In: P. Barker-Webb \& S. Berthelot. Histoire Naturelle des Îsles Canaries 2: 131-138. Paris.

Buchholtz, R., 1874. Crustaceen. Die zweite deutsche Nordpolfährt in den Jahren 1869 und 1870, unter Führung des Kapitan Karl Koldeway, 2: 262-399.

Bullis, H.R. \& Thompson, J.R., 1965. Collections by the exploratory fishing vessels "Oregon", "Silver Bay", "Combat" and "Pelican" made during 1956-1960 in the southwestern North Atlantic. United States Department of the Interior, Fish and Wildlife Service, Special Scientific Report-Fisheries, 510: 1-130.

Butler, T.H., 1980. Shrimps of the Pacific coast of Canada. Canadian Bulletin of Fisheries and Aquatic Science, 202: 1-280.

Cardoso, I. \& Young, P., 2005. Deep-sea Oplophoridae (Crustacea Caridea) from the 
southwestern Brazil. Zootaxa, 1031: 3-76.

Chace, F.A., 1940. Plankton of the Bermuda Oceanographic Expeditions, IX: The bathypelagic caridean Crustacea. Zoologica, 25: 117-209.

-1947. The deep-sea prawns of the family Oplophoridae in the Bingham Oceanographic Collection. Bulletin of the Bingham Oceanographic Collection, 11: 1-51.

,- 1986 . The caridean shrimps (Crustacea: Decapoda) of the "Albatross" Philippine Expedition 1907-1910, Part 4: Oplophoridae and Nematocarcinidae. Smithsonian Contributions to Zoology, 432: 1-82.

Crosnier, A., \& Forest, J., 1973. Les crevettes profondes de l'Atlantique Oriental tropical. Fauna Tropicale (Cahiers de l'Office de la Recherche Scientifique et Technique Outre Mer), 19: $1-409$.

Faxon, W., 1893. Reports on the dredging operations off the west coast of Central America to the Galapagos, to the west coast of Mexico, and in the Gulf of California, in charge of Alexander Agassiz, carried on by the U.S. Fish Commission Steamer "Albatross" during 1891, Lt. Commander Z.L. Tanner, U.S.N., commanding, VI: Preliminary description of new species of Crustacea. Bulletin of the Museum of Comparative Zoology at Harvard College, 24: 149-220.

Faxon, W., 1895. The stalk-eyed Crustacea: Reports on an exploration off the west coasts of Mexico, Central and South America, and off the Galapagos Islands, in charge of Alexander Agassiz, by the U.S. Fish Commission Steamer "Albatross", during 1891, Lt. Commander Z. L. Tanner, U.S.N., commanding. Memoirs of the Museum of Comparative Zoology at Harvard College, 18: 1-292.

Filhol, H., 1885. La vie au fond des mers: Les explorations sous-marines et les voyages du "Travailleur" et du "Talisman": 1-301. Paris.

Foxton, P., 1970. The vertical distribution of pelagic decapods (Crustacea Natantia) collected on the Sond cruise 1965. I. The Caridea. Journal of the Marine Biological Association of the United Kingdom, 50: 939-960.

Hanamura, Y., 1983. Pelagic shrimps (Penaeidea and Caridea) from Baja California and its adjacent region with description of a new species. Bulletin of the Biogeographical Society of Japan, 38: 51-85.

Hendrickx, M. \& Estrada-Navarrete, F., 1989. A checklist of the species of pelagic shrimps
(Penaeoidea and Caridea) from the eastern Pacific with notes on their zoogeography and depth distribution. California Cooperative Fisheries Report,30: 104-121.

— 1996 . Los camarones pelágicos (Crustacea: Dendrobranchiata y Caridea) del Pacífico Mexicano. Instituto de Ciencias del Mar y Limnología, Universidad Nacional Autónoma de México, México, D.F. 157 pp.

— \& Wicksten, M., 2004. Additional records of benthic and pelagic shrimps from the eastern tropical Pacific. In: Hendrickx, M.E. (ed.), Contributions to the Study of East Pacific Crustaceans. Vol. 3. Instituto de Ciencias del Mar y Limnología, Universidad Nacional Autónoma de México, Mazatlán, 139-141.

Hopkins, T. \& Lancraft, T., 1984. The composition and standing stock of mesopelagic micronekton at $27^{\circ} \mathrm{N} 86^{\circ} \mathrm{W}$ in the eastern Gulf of Mexico. Marine Science Institute of the University of Texas at Austin Contributions in Marine Science, 27: 143-158.

—, Gartner, J. Jr., \& Flock, M., 1989. The caridean shrimp (Decapoda; Natantia) assemblage in the mesopelagic zone of the eastern Gulf of Mexico. Bulletin of Marine Science, 45: $1-14$.

Kemp, S. W., 1939. On Acanthephyra purpurea and its allies (Crustacea Decapoda.-Hoplophoridae). Annals and Magazine of Natural History, ser. 11, 4: 548-579.

Kensley, B., 1981. The South African Museum's Meiring Naude cruises. 12. Crustacea Decapoda of the 1977, 1978, 1979 cruises. Annals of the South African Museum, 83: 49-78.

- 2006. Pelagic shrimp (Crustacea: Decapoda) from shelf and oceanic waters in the southeastern Atlantic Ocean off South Africa. Proceedings of the Biological Society of Washington, 119: 384-394.

- Tranter, H., \& Griffin, D., 1987. Deepwater decapod Crustacea from Australia (Penaeidea and Caridea). Records of the Australian Museum, 39: 263-331.

Méndez, M., 1981. Claves de identificación y distribución de los langostinos y camarones (Crustacea: Decapoda) del mar y ríos de la costa del Perú. Instituto del Mar del Perú Boletin, 5: 1-170.

Milne-Edwards, A., 1881. Description de quelques crustacés macroures provenant des grandes profondeurs de la mer des Antilles. Annals des Sciences Naturelles, Zoologie, Ser. 6, 11: 1-16. 
1883. Recueil de figures de crustacés nouveaux ou peu connus: $1-3$, Paris (privately produced).

Pequegnat, L., 1970. Deep-sea caridean shrimps from the Gulf of Mexico with descriptions of six new species. In: W.E. Pequegnat, \& F.A. Chace, Jr. (eds.), Contributions on the Biology of the Gulf of Mexico. Gulf Publishing Company, Houston, 59-123

, 1971. Caridean shrimps. In: Serial atlas of the marine environment: Folio 20: Gulf of Mexico Deep-sea fauna: Decapoda and Euphausiacea. American Geographic Society, New York, 9-11.

Pequegnat, W., \& Pequegnat, L., 1970. Station list for benthic and midwater samples taken by the R/V Alaminos 1964 to 1969. In: W.E. Pequegnat \& F.A. Chace, Jr. (eds.), Contributions on the Biology of the Gulf of Mexico. Gulf Publishing Company, Houston, 1-16.

— Bright, T.J., \& James, B.M., 1970. The benthic skimmer, a new biological sampler for deep-sea studies. In: W.E. Pequegnat, \& F.A. Chace, Jr. (eds.), Contributions on the Biology of the Gulf of Mexico. Gulf Publishing Company, Houston, 17-20.

Risso, A., 1816. Histoire naturelle des Crustacés des environs de Nice: 1-175. Paris: Librairie Greque-Latine-Allemande.

Sivertsen, E. \& Holthuis, L.B., 1956. Crustacea Decapoda (the Penaeidea and Stenopodidea excepted). Report on the scientific results of the "Michael Sars" North Atlantic Deep-Sea Expedition 1910, 5: 1-54.

Smith, S.I., 1882. Report on Crustacea. Part I. Decapoda. Reports on the results of dredging, under the supervision of Alexander Agassiz, on the east coast of the United States, during the summer of 1880 , by the U.S. Coast Survey Steamer "Blake", Commander J.R. Bartlett, U.S.N., commanding. Bulletin of the Museum of Comparative Zoology at Harvard College, 10: 1-108.

- , 1884. Report on the decapod Crustacea of the "Albatross" dredging off the east coast of the United States in 1881. Report of the Commissioner for 1882, United States Fish Commission of Fish and Fisheries, 10: 345-426.

- , 1885. On some new or little known decapod Crustacea, from recent Fish Commission dredgings off the east coast of the United States. Proceedings of the United States National Museum, 7: 493-511.

,- 1886 . Report on the decapod Crustacea of the "Albatross" dredgings off the east coast of the United States during the summer and autumn of 1884. Report ofthe Commissioner for 1885, United States Commission of Fish and Fisheries, 13: 605-705.

Springer, S. \& Bullis, H. Jr., 1956. Collections by the "Oregon" in the Gulf of Mexico. U.S. Department of the Interior, Bureau of Commercial Fisheries, Special Scientific Report, Fisheries, 196: 1-134.

Stephensen, K., 1923. Decapoda-Macrura excl. Sergestidae (Penaeidae, Pasiphaeidae, Hoplocaridae, Nematocarcinidae, Scyllaridae, Eryonidae, Nephropsidae, Appendix). Report on the Danish Oceanographical Expedfitions 1908-10 to theMediterranean and Adjacent Seas, 2 (D. 3): 1-85.

Takeda, M. \& Okutani, T., 1983. Crustaceans and mollusks trawled off Suriname and French Guiana. Tokyo: Japan Marine Fishery Resource Research Center. 354 pp.

—, \& Hatanaka, H., 1984. Records of decapod crustaceans from the southwestern Atlantic collected by the Japanese fisheries research trawlers. Bulletin of the National Science Museum, Tokyo, Series A, 10: 7-24.

Thompson, J.R., 1963. The bathyalbenthic cardiean shrimps of the southwestern North Atlantic. Ph.D. dissertation, Department of Zoology, Duke University. 502 pp.

Wasmer, R., 1986. Pelagic shrimps of the family Oplophoridae (Crustacea: Decapoda) from the Pacific sector of the southern ocean: USNS Eltanin cruises 10, 11, 14-16, 19-21, 24 and 25. Biology of the Antarctic Seas XVII. Antarctic Research Series, 44: 29-68.

- , 1993. Pelagic shrimps (Crustacea: Decapoda) from six USNS Eltanin cruises in the southeastern Indian Ocean, Tasman Sea, and southwestern Pacific Ocean to the Ross Sea. Biology of the Antarctic Seas XXII Antarctic Research Series, 58: 49-91.

Wicksten, M., 2002. Midwater decapods of the northeastern Pacific. In: Hendrickx, M. E. (ed.) Contributions to the Study of East Pacific Crustaceans. Vol. 1. Instituto de Ciencias del Mar y Limnología, Universidad Nacional Autónoma de México, Mazatlán, 127-144.

—, \& Packard, J., 2005. A zoogeographic analysis of decapod crustaceans of the continental slopes of the Gulf of Mexico. Deep-Sea Research I, 52: 1745-1765.

Wood-Mason, J., 1891. Natural history notes from H.M. Indian marine survey steamer "Investigator", commander R.F. Hoskyn, R.N., 
commanding. On the results of deep-sea dredging during the season 1890-91. Annals and Magazine of Natural History, Ser. 6, 9: 265-275.
Addresses. - (LP) Linda H. Pequegnat, 8463 Paseo del Ocaso, La Jolla, California, 92037, U.S.A.; (MW) Department of Biology, Texas A\&M University, College Station, Texas 778433258 U.S.A.

E-mail._ (MW) Wicksten@mail.bio.tamu.edu 